\title{
GC-MS analysis of bioactive constituents of Aristolochia bracteolata Linn with in-vitro antioxidant properties
}

\author{
Trayee Sarkar Das, Latha Ramesh, Paul Agastian* \\ Research Department of Plant Biology and Biotechnology, Loyola College, Nungambakkam, Chennai, India.
}

\begin{tabular}{|c|c|}
\hline ARTICLE INFO & ABSTRACT \\
\hline Article history: & \multirow{9}{*}{ 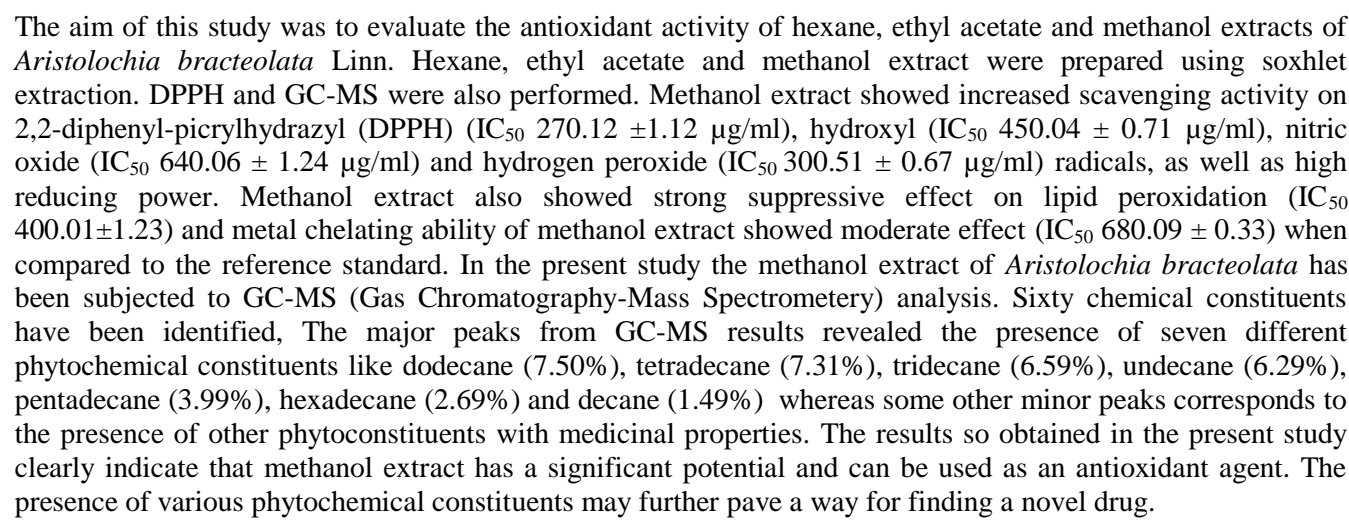 } \\
\hline Received on: $12 / 07 / 2016$ & \\
\hline Revised on: 02/09/2016 & \\
\hline Accepted on: 12/10/2016 & \\
\hline Available online: $28 / 12 / 2016$ & \\
\hline Key words: & \\
\hline Antioxidant, Aristolochia & \\
\hline bracteolata, GC-MS, & \\
\hline Phytoconstituents. & \\
\hline
\end{tabular}

\section{INTRODUCTION}

Plants have been used as a source of traditional medicine since years. Many medicinal plants contain potent antioxidant activities and many are eminent sources for phytochemicals. Free radicals are pivotal cause of aging, coronary heart disease, inflammation, cancer, stroke, diabetes mellitus (Cheng et al., 2003; Slater, 1984). During oxidative stress, reactive oxygen molecules (ROS) suchas hydroxyl $(\mathrm{OH})$, superoxide $\left(\mathrm{O}_{2}^{-}, \mathrm{OOH}\right)$, and peroxyl (ROO) radicals are produced. The ROS play its major role in the pathogenesis of neurodegenerative disorders, cancer, cardiovascular diseases, cataracts, atherosclerosis, and inflammation (Aruoma, 1998).

* Corresponding Author

Paul Agastian, Research Department of Plant Biology and

Biotechnology, Loyola College, Nungambakkam, Chennai, India.

Email: agastianloyolacollege @ gmail.com
In the cells, Reactive oxygen species (ROS) are produced by exogenous environmental agents and cellular metabolism. ROS are produced by redox cycling (Halliwell and Gutteridge, 1999). Overproduction of ROS can damagenucleic acids, carbohydrates, proteins, lipids and enzymes leading to various diseases. To overcome deleterious affects of several damages, living systems do have specific pathways but sometimes these repair mechanisms fail to keep pace with such deleterious effects (Halliwell, 1995; Nilsson, 2004). Antioxidants play a major role in scavenging free radicals. This in turn reduces the risk of cardiovascular diseases and cancer. Many plant extracts and phytochemicals have antioxidant activity (Al-Saikhan et al., 1995, Bergman et al., 2001; Cao et al., 1996; Oomah et al., 1994; Wang et al., 1996; Yen and Duh, 1995). Therefore search for novel natural antioxidants of plant origin has increased. The present work evaluates the possible antioxidative effects of hexane, ethyl acetate and methanol extract of whole plant of Aristolochia bracteolata. 
Many natural antioxidants have already been isolated such as oilseeds, cereal crops, leaves, spices, vegetables, roots, and herbs (Ramarathnam et al., 1995). Phenolic compounds are reported to quench oxygen-derived free radicals (Wanasundara and Shahidi, 1996; Yuting et al., 1990). Also, phenolic compounds neutralize free radicals in various model systems (Ruch et al., 1989; Silvaet al., 1991; Zhang et al., 1996). Nowadays the most commonly used antioxidants are butylated hydroxyanisole (BHA), tert-butyl hydroquinone, butylated hydroxytoluene (BHT) and propyl gallate. However, BHA and BHT have been suspected of being responsible for liver damage and carcinogenesis (Whysner etal., 1994). Therefore, there is an increasing interest in natural and safer antioxidants. In this study, we evaluated the antioxidant activity by employing various in vitro assay systems, such as the DPPH/superoxide/nitric oxide radical scavenging, reducing power and iron ion chelation, in order to understand the usefulness of this plant as a food stuff as well as in medicine.

\section{Scientific classification}

Kingdom: Plantae Order: Piperales Family: Aristolochiaceae Subfamily: Aristolochioideae Genus: Aristolochia Species: bracteolata Aristolochia bracteolata has been reported to be used for inflammatory diseases, fever and insect bites. The whole plant is very bitter and used as abortifacient alterative, purgative, antiperiodic, emmenagogue, anthelmintic, antipyretic, anti-inflammatory agents. The stem and the root contain the alkaloid aristolochic acid. It should be used with great caution since the plant can be toxic to mammals. The dried, powdered root has been shown to increase the contractions of the uterus during labor. The leaves and roots are used to rid the body of Guinea worm (a parasitic infection caused by a nematode). Externally, its juice is applied to foul and neglected ulcers to destroy insect larvae. It is also used to treat scorpion bites.

\section{MATERIALS AND METHODS}

\section{Collection of plant material}

Plants were obtained from places near Coimbatore, South India. The plant specimen Aristolochia bracteolata was identified, certified and the voucher specimen number (LCH110) was deposited at Loyola college herbarium in the department of Plant Biology and Biotechnology, Chennai, India.

\section{Preparation of the extract}

The solvents which were used for preparation of extract were ethyl acetate, hexane, and methanol. Whole plant powder $(100 \mathrm{~g})$ was taken and the extract was prepared by soxhlet extraction method using $300 \mathrm{ml}$ of each solvent (low polarity to high polarity). The extract was then filtered using ordinary filter paper. Then the obtained filtrate were concentrated under reduced pressure at $40^{\circ} \mathrm{C}$ using rotary evaporator and stored in a refrigerator at 2 to $8^{\circ} \mathrm{C}$ for further experiments.

\section{Chemicals and reagents}

DPPH (1,1-diphenyl,2-picrylhydrazyl), PMS (phenazine methosulphate), NBT (nitro- blue tetrazolium), ferric chloride, NADH (nicotinamide adenine dinucleotide phosphate reduced), TCA (trichloroacetic acid) and BHT (butylated hydroxyltoluene) were obtained from Sigma chemical co., USA. Ascorbic acid was obtained from SD fine chem Ltd, Biosar, India. ferrozine, folin phenol reagent and Tween 40 were purchased from Hi-Media Pvt.Ltd. Mumbai, India. All the other chemicals were of analytical grade.

\section{Reducing power activity}

The reducing power of Aristolochia bracteolata hexane, ethyl acetate and methanol extracts were evaluated according to the method of Oyaizu (Oyaizu, 1986). Extracts with different concentration $(200-1000 \mathrm{~g} / \mathrm{ml})$ were suspended in distilled water and mixed with $2.5 \mathrm{ml}$ of $0.2 \mathrm{M}$ phosphate buffer ( $\mathrm{pH} \mathrm{6.6)}$ ), and 2.5 $\mathrm{ml}$ of $1 \%$ potassium ferricyanide and was incubated at $50{ }^{\circ} \mathrm{C}$ for 20 min. It was then centrifuged at $3000 \mathrm{rpm}$ for $10 \mathrm{~min}$ by adding 2.5 $\mathrm{ml}$ of $10 \%$ trichloroacetic acid. The supernatant $(2.5 \mathrm{ml})$ was mixed with distilled water $(2.5 \mathrm{ml})$ and ferric chloride $(0.5 \mathrm{ml}$, $0.1 \%$ ). Absorbance was read at $700 \mathrm{~nm}$. Butylated hydroxytoluene (BHT) was used as standard.

\section{DPPH radical scavenging assay}

DPPH quenching ability of solvent extract was measured according to Hanato et al. (Hanato et al., 1988). Extracts (ethyl acetate, hexane, and methanol) with different concentration ranging (200-1000 $\mu \mathrm{g} / \mathrm{ml})$ were mixed with DPPH solution $(0.15 \%)$ in methanol. Then it was incubated at darkfor $10 \mathrm{~min}$ and the absorbance was read at $515 \mathrm{~nm}$. The antiradical activity was expressed as $\mathrm{IC}_{50}(\mu \mathrm{g} / \mathrm{ml})$, (the antiradical dose required to cause a $50 \%$ inhibition). Vitamin $\mathrm{C}$ was used as standard. The ability to scavenge the DPPH radical was calculated using the following formula:

DPPH radical scavenging activity $(\%)=\left[\left(\mathrm{A}_{0}-\mathrm{A}_{1} / \mathrm{A}_{0}\right) \times 100\right] \ldots(1)$

Where $A_{0}$ is the absorbance of the control, and $A_{1}$ is the absorbance of sample or the standard sample.

\section{Hydroxyl radical scavenging activity}

The hydroxyl scavenging assay was performed as described by the method of Elizabeth and Rao (Elizabeth and Rao, 1990) with slight changes. The reaction mixture contained $100 \mu \mathrm{l}$ of $28 \mathrm{mM}$ 2-deoxy-2-ribose (dissolved in phosphate buffer, $\mathrm{pH}$ $7.4)$, extracts of various concentrations hexane, ethyl acetate and methanol $(200-1000 \mu \mathrm{g} / \mathrm{ml}), 100 \mu \mathrm{H} 2 \mathrm{O} 2(1 \mathrm{mM})$ and $100 \mu \mathrm{l}$ ascorbic acid (1 mM), $200 \mu \mathrm{l}$ of $\mathrm{IM}$ ferric chloride and $1.04 \mathrm{Mm}$ Ethylenediaminetetraacetic acid (EDTA) $(1: 1 \mathrm{v} / \mathrm{v})$. The mixture was incubated for $1 \mathrm{~h}$ at $37^{\circ} \mathrm{C}$. The absorbance was read at $532 \mathrm{~nm}$ against the blank solution. Vitamin $\mathrm{C}$ was used as a positive control. The scavenging activity was calculated using formula (1). 


\section{Nitric oxide scavenging activity}

It can be estimated by the use of GriessIllosvoy reaction (Garratt, 1964). Here, GriessIllosvoy reagent was modified using $\mathrm{N}$-(1-Naphthyl) ethylenediamine dihydrochloride $(0.1 \% \mathrm{w} / \mathrm{v})$. The reaction mixture $(3 \mathrm{ml})$ containing sodium nitroprusside $(10 \mathrm{mM}$, $2 \mathrm{ml})$, phosphate buffer saline $(0.5 \mathrm{ml})$ and different concentration of hexane, ethyl acetate and methanol extract $(200-1000 \mu \mathrm{g} / \mathrm{ml})$ was incubated at $25^{\circ} \mathrm{C}$ for $150 \mathrm{~min}$.

After incubation, $0.5 \mathrm{ml}$ of the reaction mixture containing nitrite was pipetted and mixed with $1 \mathrm{ml}$ of sulphanilic acid reagent $(0.33 \%$ in $20 \%$ glacial acetic acid) and allowed to stand for $5 \mathrm{~min}$. Then, $1 \mathrm{ml}$ of $\mathrm{N}$-(1-Naphthyl) ethylenediamine dihydrochloride (1\%) was added and allowed to stand for $30 \mathrm{~min}$. The absorbance was measured at $540 \mathrm{~nm}$. Ascorbic acid was used as standard. The scavenging activity was calculated using the formula (1).

\section{Hydrogen peroxide radical scavenging assay}

The ability of the extract to scavenge hydrogen peroxide was determined according to the method of Ruch et al., 1989. A solution of hydrogen peroxide $(2 \mathrm{mmol} / \mathrm{l})$ was prepared in phosphate buffer ( $\mathrm{pH}$ 7.4). All the extracts with concentrations $(200-1000 \mu \mathrm{g} / \mathrm{ml})$ were added to hydrogen peroxide solution $(0.6 \mathrm{ml})$. After $10 \mathrm{~min}$, absorbance was read at $230 \mathrm{~nm}$ against blank solution and compared with ascorbic acid, the standard.

\section{Lipid peroxidation in rat liver homogenate}

The peroxidation effect of the extracts on lipid peroxidation was determined according to the thiobarbituric acid method. Ferric chloride- hydrogen peroxide was used to produce the liver homogenate peroxidation (Yen and Hsieh, 1998). The reaction mixture containing $0.2 \mathrm{ml}$ of all the three extracts $(200-$ $1000 \mu \mathrm{g} / \mathrm{ml}$ ) with $1.0 \mathrm{ml}$ of $1 \%$ liver homogenate (each $100 \mathrm{ml}$ homogenate solution contains $1.0 \mathrm{~g}$ rat liver), then $50 \mu \mathrm{l}$ of ferric chloride $(0.5 \mathrm{mM})$ and hydrogen peroxide $(0.5 \mathrm{mM})$. The mixture was incubated at $37^{\circ} \mathrm{C}$ for $60 \mathrm{~min}$.

After that, $1.0 \mathrm{ml}$ of thiobarbituric acid (0.67\%) and trichloroacetic acid (15\%) was added and heated in boiled water for $15 \mathrm{~min}$. The absorbance was read at $532 \mathrm{~nm}$. Ascorbic acid was used as the positive control. The percentage of lipid peroxidation effect was calculated according to formula (1).

\section{Metal Chelating activity}

The chelation of ferrous ions byhexane, ethyl acetate and methanol extract of Aristolochia bracteolata were estimated by the method of Dinis et al. (1994). The different concentrations of extract $(200-1000 \mu \mathrm{g} / \mathrm{ml})$ were added to $2 \mathrm{mM} \mathrm{FeCl}_{2}(0.05 \mathrm{ml})$. Then it was added with $5 \mathrm{mMferrozine}(0.2 \mathrm{ml})$, this mixture was shaken vigorously and left to stand at room temperature for 10 min. Absorbance of the solution was read at $562 \mathrm{~nm}$. EDTA was used as a positive control. The percentage inhibition of ferrozine$\mathrm{Fe}^{2+}$ complex formation was calculated using the formula (1).

\section{Statistical analysis}

The data for physiological and biochemical parameters were analyzed and expressed as meanof triplets of the same experiments $\pm \mathrm{SD}$. The $\mathrm{IC}_{50}$ values were calculated from linear regression analysis. Results were processed by Microsoft Excel (2007).

\section{GC - MS analysis}

Two micro liter of sample was injected into the gas chromatograph HP-6890(GC) equipped and coupled to a mass detector MS (HP 5972). Separation of compound was achieved using RTX volatile capillary column $(60 \mathrm{~m} \times 0.32 \mathrm{~mm} \times 0.5 \mu)$. Injection port temperature was ensured as $200^{\circ} \mathrm{C}$ with $250^{\circ} \mathrm{C}$ as transfer temperature. The oven temperature was elevated from $40^{\circ} \mathrm{C}$ (2 min) to $220^{\circ} \mathrm{C}$ at $15^{\circ} \mathrm{C} / \mathrm{min}$ with final hold $5 \mathrm{~min}$. The ionization voltage was $70 \mathrm{eV}$. The carrier gas helium was passed through at a flow rate of $1 \mathrm{ml} / \mathrm{min}$. The compounds were identified with the help of NIST Libraries based on their molecular mass.

Interpretation of mass spectrum GC-MS was conducted using the database of National Institute Standard and Technology (NIST) having many patterns. The spectrum of the unknown component was compared with the spectrum of the known components stored in the NIST library. The name, molecular weight and structure of the components of the test materials were ascertained.

\section{RESULTS}

\section{In vitro antioxidant assays}

\section{Reducing power activity}

Fig. 1(a) shows the reductive capabilities of hexane, ethyl acetate and methanol extracts of Aristolochia bracteolata compared to butylated hydroxytoluene. The reducing power of methanol extract was very potent when compared to hexane and ethyl acetate extracts and the reducing power of the extract was increased with quantity of sample. The plant extract could reduce the most $\mathrm{Fe}^{3+}$ ions, which had a lesser reductive activity than the standard of butylatedhydroxy toluene.

\section{DPPH radical scavenging assay}

The methanol extract exhibited a significant dose dependent inhibition of DPPH activity compared to ethyl acetate and hexane extract with a $50 \%$ inhibition $\left(\mathrm{IC}_{50}\right)$ at a concentration of $270.12 \pm 1.12,350.01 \pm 0.85$ and $600.23 \pm 1.20 \mu \mathrm{g} / \mathrm{ml}$ respectively. The results are presented in Fig. $1(\mathrm{~b})$. The $\mathrm{IC}_{50}$ value of vitamin $\mathrm{C}$ was $220.11 \pm 0.63 \mu \mathrm{g} / \mathrm{ml}$.

\section{Hydroxyl radical scavenging activity}

The results for hydroxyl scavenging assay is shown in Fig.1(c). The concentrations for $50 \%$ inhibition for methanol, ethyl acetate and hexane extract were found to be $450.04 \pm 0.71,530.12$ \pm 1.98 and $690.22 \pm 1.16 \mu \mathrm{g} / \mathrm{ml}$ respectively. The $\mathrm{IC}_{50}$ value of vitamin $\mathrm{C}$ was $220.05 \pm 0.97 \mu \mathrm{g} / \mathrm{ml}$. 


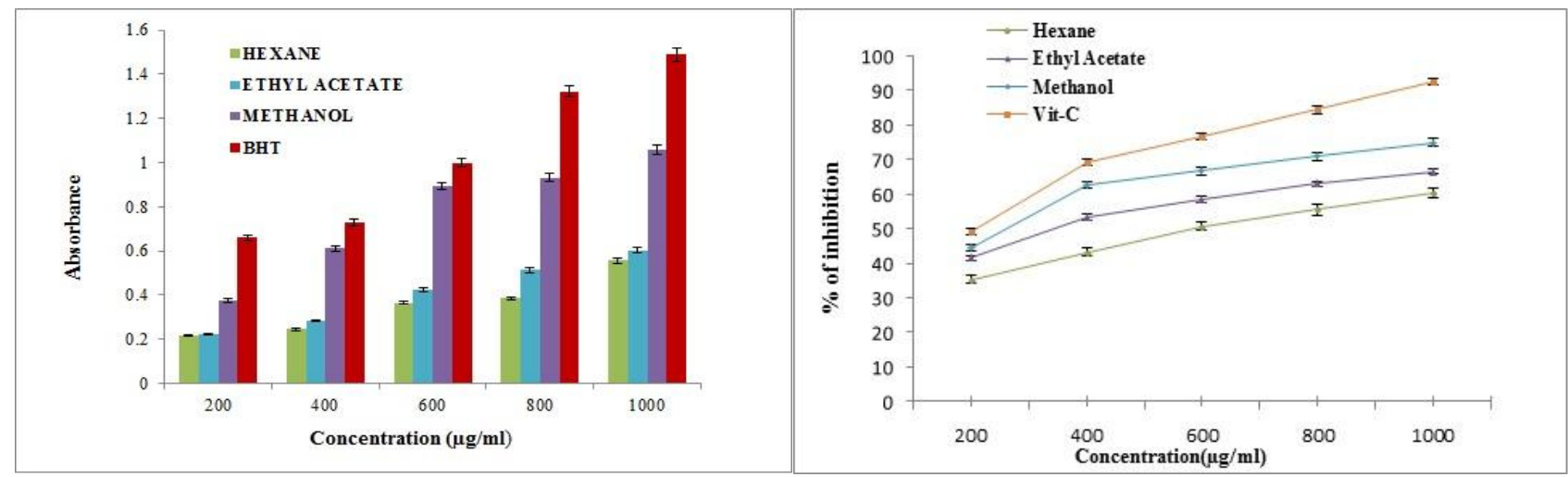

(a)

(b)

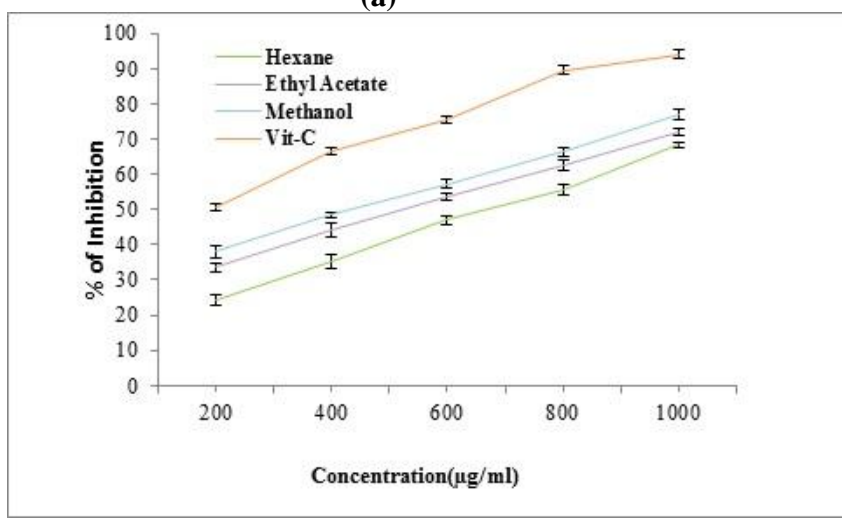

(c)

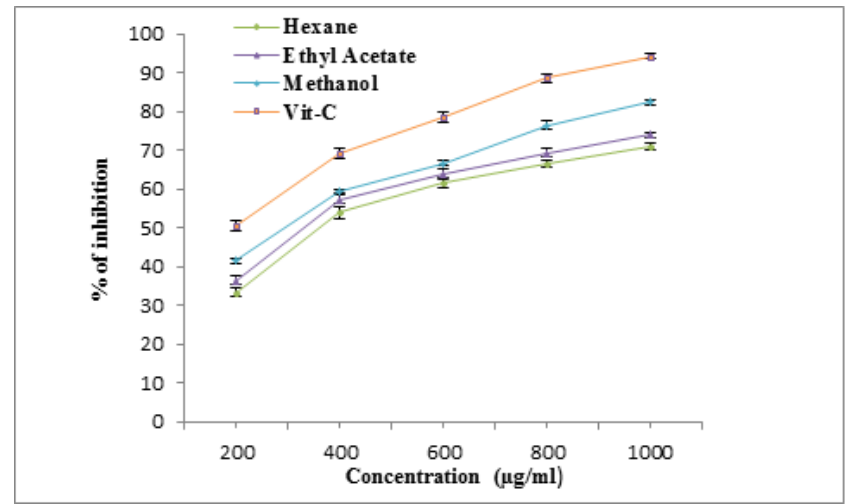

(e)

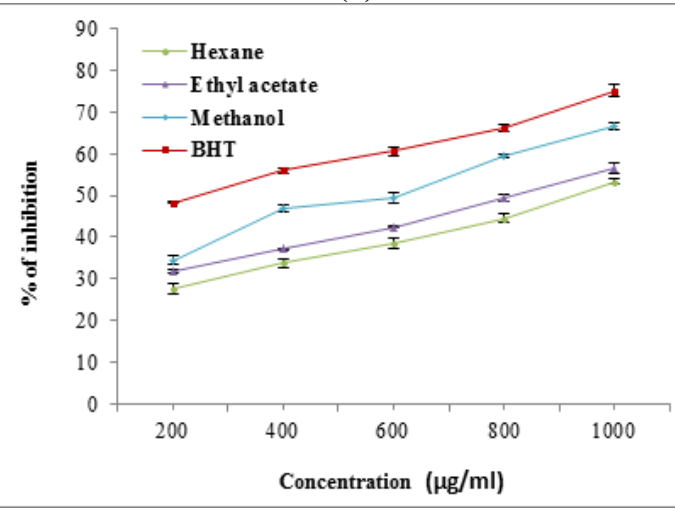

(d)

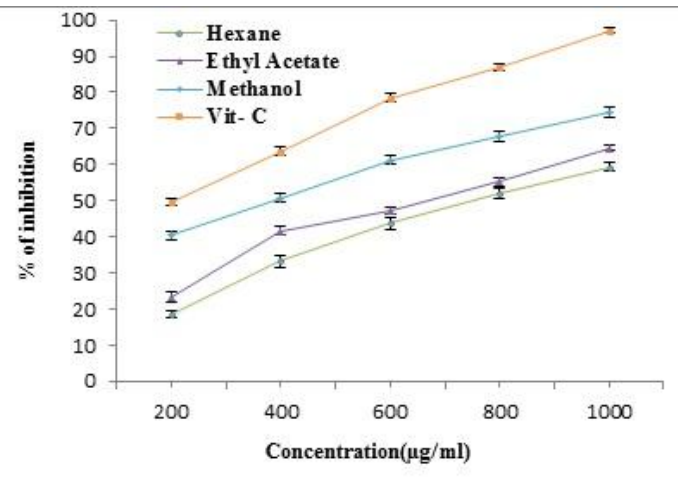

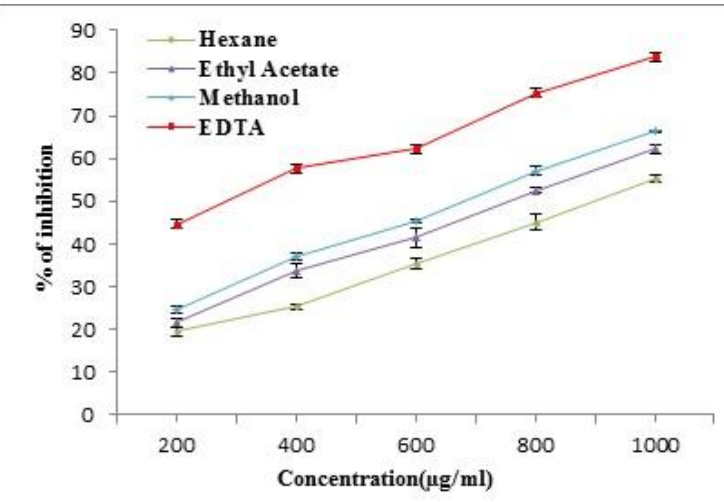

(g)

Fig. 1: (a) Reductive ability of different concentrations $(200-1000 \mu \mathrm{g} / \mathrm{ml})$ of Aristolochia bracteolata hexane, ethyl acetate, methanol extracts and BHT. (b) DPPH scavenging effect of different concentrations (200-1000 $\mu \mathrm{g} / \mathrm{ml})$ of Aristolochia bracteolata hexane, ethyl acetate, methanol extracts and vitamin C. (c) Hydroxyl radical scavenging effect of different concentrations $(200-1000 \mu \mathrm{g} / \mathrm{ml})$ of Aristolochia bracteolatahexane, ethyl acetate, methanol extracts and vitamin C. (d) Nitric oxide scavenging effect of different concentrations (200-1000 $\mu \mathrm{g} / \mathrm{ml})$ of Aristolochia bracteolata hexane, ethyl acetate, methanol extracts and vitamin C. (e) Hydrogen peroxide scavenging effect of different concentrations (200-1000 $\mu \mathrm{g} / \mathrm{ml})$ of Aristolochia bracteolatahexane, ethyl acetate, methanol extracts and vitamin C. (f) Antilipid peroxidation effect of different concentrations (200-1000 $\mu \mathrm{g} / \mathrm{ml})$ of Aristolochia bracteolata hexane, ethyl acetate, methanol extracts and vitamin C. (g) Metal chelating effects of different concentrations (200-1000 $\mu \mathrm{g} / \mathrm{ml})$ of Aristolochia bracteolata hexane, ethyl acetate, methanol extracts and vitamin $\mathrm{C}$. Each value represents the mean \pm SEM of triplicate experiments. 

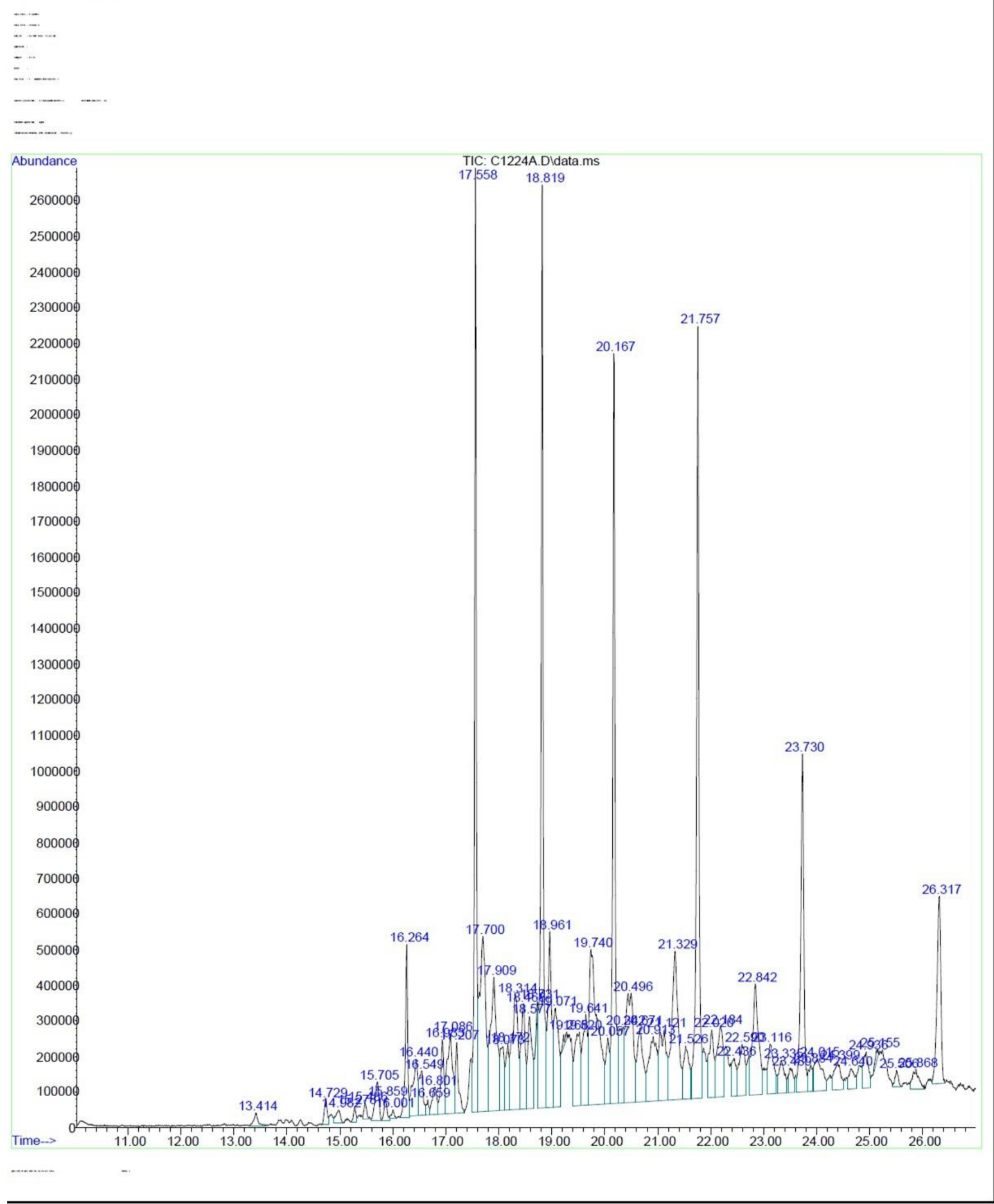

Fig 2: GC-MS analysis of Aristolochia bracteolata. 


\section{Nitric oxide scavenging activity}

The scavenging of nitric oxide by methanol extract was increased in a dose-dependent manner as illustrated in Fig. 1(d). At concentration of $640.06 \pm 1.24,830.13 \pm 0.92,930.32 \pm 0.81$ $\mu \mathrm{g} / \mathrm{ml}$ of methanol, ethyl acetate and hexane extract, $50 \%$ of nitric oxide generated during incubation was scavenged. The $\mathrm{IC}_{50}$ value of vitamin $\mathrm{C}$ was $250.15 \pm 0.23 \mu \mathrm{g} / \mathrm{ml}$.

\section{Hydrogen peroxide scavenging activity}

Hydrogen peroxide anion scavenging activities of all the three extracts are given in Fig. 1(e). The 50\% of hydrogen peroxide anion radical generation was scavenged at the concentration of $300.51 \pm 0.67,330.23 \pm 0.97$ and $370.71 \pm 1.25$ $\mu \mathrm{g} / \mathrm{ml}$ for methanol, ethyl acetate and hexane extracts respectively. The $\mathrm{IC}_{50}$ value of vitamin $\mathrm{C}$ was $200.02 \pm 1.39 \mu \mathrm{g} / \mathrm{ml}$.

\section{Lipid peroxidation in rat liver homogenate}

Activity of all the extracts on lipid peroxidation is shown in Fig. 1(f). The methanol, ethyl acetate and hexane extract showed $50 \%$ inhibition of lipid peroxidation at the concentration of $400.01 \pm 1.23,680.17 \pm 0.95$ and $760.11 \pm 1.55 \mu \mathrm{g} / \mathrm{ml}$ respectively. The $\mathrm{IC}_{50}$ value of $\mathrm{BHT}$ was $220.21 \pm 1.16 \mu \mathrm{g} / \mathrm{ml}$.

\section{Metal Chelating activity}

The activity of all the three extracts on chelating the ferrous ions is shown in Fig. 1(g). Methanol, ethyl acetate and hexane extract showed $50 \%$ of chelation generation at the concentration of $680.09 \pm 0.33,760.17 \pm 0.57$ and $900.54 \pm 1.12$ $\mu \mathrm{g} / \mathrm{ml}$ respectively. The $\mathrm{IC}_{50}$ value of EDTA was $300.13 \pm 1.15$ $\mu \mathrm{g} / \mathrm{ml}$.

\section{GC - MS analysis}

The GC-MS analysis of methanolic extract clearly showed the presence of sixty phytoconstituents. The GC-MS chromatogram of the compounds with their peaks was shown in Fig. 2. The phytoconstituents with their retention time (RT), molecular weight, molecular formula (MW) and concentration (peak area\%) are presented in Table 1.

Table 1: Phytocomponents identified in the Aristolochia bracteolata.

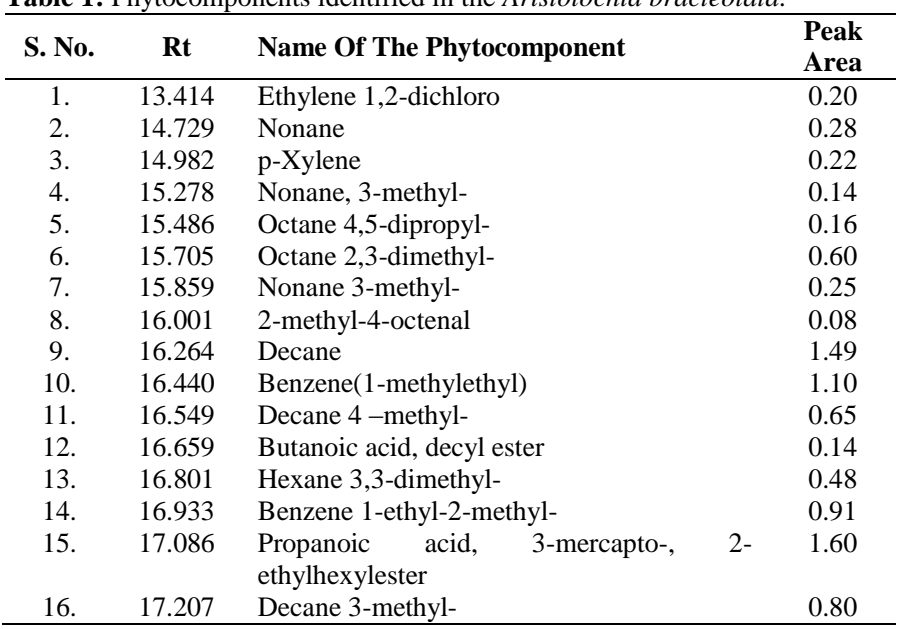

\begin{tabular}{|c|c|c|c|}
\hline 17. & 17.558 & Undecane & 6.29 \\
\hline 18. & 17.700 & Benzene 1,4-diethyl- & 4.12 \\
\hline 19. & 17.909 & 1-Butene 1,4-dichloro- & 3.25 \\
\hline 20. & 18.073 & o-Cymene & 0.89 \\
\hline 21 & 18.172 & Benzene 4-ethyl-1,2-dimethyl- & 0.82 \\
\hline 22. & 18.314 & Nonane, 5-(1-methylpropyl)- & 2.72 \\
\hline 23. & 18.468 & Decane, 1,1'-oxybis- & 1.68 \\
\hline 24. & 18.577 & 3-Octyne & 1.52 \\
\hline 25 . & 18.731 & 1,3-Cyclopentadiene, 1,2,3,4-tetra & 0.15 \\
\hline 26. & 18.819 & Dodecane & 7.50 \\
\hline 27. & 18.961 & Undecane, 2,6-dimethyl- & 2.54 \\
\hline 28. & 19.071 & 2-Piperidinone, N-[4-bromo-n-butyl]- & 1.79 \\
\hline 29. & 19.268 & $\begin{array}{l}\text { 1b,5,5,6a-Tetramethyl-octahydro-1-oxa- } \\
\text { cyclopropa[a]inden-6-one }\end{array}$ & 0.13 \\
\hline 30. & 19.520 & 3-Octyne, 6-methyl- & 1.65 \\
\hline 31. & 19.641 & 2-Isopropyl-5-methyl-1-heptanol & 1.65 \\
\hline 32. & 19.740 & Heptane, 2,6-dimethyl- & 4.84 \\
\hline 33. & 20.057 & Benzene, (3-chloro-1-methyl-1-propenyl)- & 1.00 \\
\hline 34. & 20.167 & Tridecane & 6.59 \\
\hline 35 . & 20.342 & 2,8-Decadiyne & 1.38 \\
\hline 36. & 20.496 & Diazoprogesterone & 3.17 \\
\hline 37. & 20.671 & 5-Tetradecene, $(\mathrm{E})$ - & 1.67 \\
\hline 38. & 20.913 & $\begin{array}{l}\text { Oxalic acid, 3,5-difluorophenyl undecyl } \\
\text { ester }\end{array}$ & 1.88 \\
\hline 39. & 21.121 & 5-Butyl-5-ethylheptadecane & 1.92 \\
\hline 40 . & 21.329 & Dodecane, 2,6,10-trimethyl- & 3.57 \\
\hline 41. & 21.526 & Stigmasterol & 1.08 \\
\hline 42. & 21.757 & Tetradecane & 7.31 \\
\hline 43. & 22.020 & 1,5-Heptadiyne & 1.14 \\
\hline 44. & 22.184 & Benzene, 1-ethenyl-4-methyl- & 1.63 \\
\hline 45. & 22.436 & 2-Cyclopenten-1-one, 3-bromo- & 0.62 \\
\hline 46. & 22.590 & Cyclododecanol, 1-ethenyl- & 1.15 \\
\hline 47. & 22.842 & Dodecane, 2,6,11-trimethyl- & 2.52 \\
\hline 48. & 23.116 & $\begin{array}{l}\text { Butanoic acid, 4-(1,1-dimethylethoxy)-3- } \\
\text { hydroxy-2-methyl-, ethyl ester, }\left[\mathrm{r}-\left(\mathrm{R}^{*}, \mathrm{~S}^{*}\right)\right]-\end{array}$ & 1.03 \\
\hline 49. & 23.335 & $\begin{array}{l}\text { 9-Methyltricyclo[4.2.1.1(2,5)]deca-3,7- } \\
\text { diene-9,10-diol }\end{array}$ & 0.70 \\
\hline 50. & 23.489 & Cyclododecanol, 1-ethenyl- & 0.44 \\
\hline 51. & 23.730 & Pentadecane & 3.99 \\
\hline 52. & 23.884 & 11-Tetradecyn-1-ol acetate & 0.34 \\
\hline 53. & 24.015 & $\begin{array}{l}\text { Naphthalene, 1,2,3,4-tetrahydro-5, } \\
\text { dimethyl- }\end{array}$ & 0.95 \\
\hline 54. & 24.399 & $\begin{array}{l}\text { 9,12-Octadecadienoic acid (Z,Z)-,2- } \\
\text { (acetyloxy)-1-[(acetyloxy)methyl]ethyl } \\
\text { ester }\end{array}$ & 0.69 \\
\hline 55. & 24.640 & Benzene, 2,5-cyclohexadien-1-yl- & 0.45 \\
\hline 56. & 24.936 & Dodecane, 2-methyl- & 0.66 \\
\hline 57. & 25.155 & Dispiro[2.2.2.0]octane, 4,5-cis-diphenyl- & 0.14 \\
\hline 58. & 25.506 & Sulfurous acid, butyl tetradecyl ester & 0.20 \\
\hline 59. & 25.868 & Citronellol & 0.47 \\
\hline 60. & 26.317 & Hexadecane & 2.69 \\
\hline
\end{tabular}

\section{DISCUSSION}

In the present study, three extracts of Aristolochia bracteolata were studied for in vitro antioxidant activity using standard methods. The methanol extracts have shown more antioxidant activity as compared to other two extracts. The variations in activity may be due to the fact that diversity in the basic chemical structure of phytoconstituents possesses different degree of antioxidant activity against different free radicals. Plant phenolics are known to exhibit potent antioxidant activity (Jaggi and Kapoor, 1999). Hence, the observed antioxidant activity of the extracts of Aristolochia bracteolata may be due to the presence of these constituents.

For the measurements of the reductive ability, we studied the $\mathrm{Fe}^{3+}$ to $\mathrm{Fe}^{2+}$ transformation in the presence of Aristolochia 
bracteolata extracts, using the method of Oyaizu (Oyaizu, 1986). The reducing power increased with increasing concentration of the extract and thus methanol extract with increasing concentration of $1000 \mu \mathrm{g} / \mathrm{ml}$ shows absorbance at 1.05 . The reducing capacity of a compound may serve as a significant indicator of its potential antioxidant activity (Meir et al.,1995). In previous studies, Aristolochia bracteolata antioxidant investigations of the ethanol extract along with its two successive fractions using nitric oxide and (DPPH)- induced free radical assay methods showed good free radical scavenging activity (Shirwaikar and Somashekar, 2003).

DPPH test is usually used to evaluate antioxidative activity of antioxidants Oyaizu (Oyaizu, 1986). This method is based on the formation of DPPH-H by the reaction due to reduction of alcoholic DPPH solution (Williams et al., 1995). In the present study, methanol extract proved to be a best DPPH scavenger (which reduces the stable radical DPPH to the yellowcolored diphenylpicrylhydrazine) as compared to hexane and ethyl acetate extract. Hydroxyl radical scavenging capacity of an extract is directly related to its antioxidant activity(Babu et al., 2001).

Previous studies have shown that the plant Aristolochia bracteolata acted as a free radical scavenger against nitric oxide (Somashekar and Shirwaikar, 2003). In the present study, Methanol extract was found best to scavenge nitric oxide as compared to hexane and ethyl acetate extract. Nitric oxide plays an important role in various types of inflammatory processes in the animal body. Nitric oxide radical inhibition study showed that the extract was a potent scavenger of nitric oxide. The extract inhibited nitrite formation by competing with oxygen to react with nitric oxide directly and also to inhibit its synthesis. Scavengers of nitric oxide competed with oxygen leading to reduced production of nitric oxide (Marcocci et al., 1994). In the PMS-NADH-NBT system, superoxide anion derived from the dissolved oxygen by PMS/NADH coupling reaction reduces NBT. The decrease in the absorbance at $560 \mathrm{~nm}$ with antioxidants thus indicates the consumption of the generated superoxide anion in the reaction.

Methanol extract inhibited free radical mediated deoxyribose damage remarkably. Lipid peroxidation is an oxidative alteration of polyunsaturated fatty acids in the cell membranes that generates a number of degradation products. Malondialdehyde (MDA), one of the products of lipid peroxidation, has been studied widely as an index of lipid peroxidation and as a marker of oxidative stress (Janero, 1990). Methanol extract showed a strong inhibition of lipid peroxidation.

The chelating of ferrous ions by the extract was estimated by the method of Dinis et al. (Dinis et al., 1994). Ferrozine can quantitatively form complexes with $\mathrm{Fe}^{2+}$. In the presence of other chelating agents, the complex formation is disrupted with the result that the red color of the complexes decreases. Measurement of the rate of color reduction therefore allows estimation of the chelating activity of the coexisting chelator (Yamaguchi et al., 2000). In our study methanol extract reveals effective capacity for iron binding, suggesting that action as an antioxidant may be related to its iron binding capacity.
In the present study, methanol extract was given for GCMS analysis where it showed around sixty phytocomponents. Some of the major peaks correspond to decane, undecane, dodecane, tridecane, tetradecane, pentadecane, hexadecane etc whereas some useful phyto components with medicinal applications comprising minor peaks were stigmasterol, 2piperidinone, cymene etc. Rests of the phytocomponents are also enlisted in table 1 . The gas chromatography shows various heights of the peak which indicate the relative concentrations of the components present in the plant. The nature and structure of the compounds are identified by using the mass spectrometer. It also analyzes the compounds which are eluted at different times. These mass spectra act as fingerprint of that compound which is identified from the data library. In a previous study, 13 compounds were identified by GC-MS analysis from Aristolochia krysagathra (Jegadeeswari et al., 2012).

\section{CONCLUSION}

From the above results, it is concluded that the methanol extract of Aristolochia bracteolate has significant and promising antioxidant activity. GC-MS analysis is the first step towards understanding the nature of active principles in this medicinal plant. The methanol extract of this plant showed presence of sixty phyto components with various applications which merits further investigation for isolation of individual phytochemical constituents which may pave a way for finding a novel drug.

\section{ACKNOWLEDGEMENT}

Firstly, I would like to show my gratitude to Dr. M. F. Valan, assistant professor from department of Chemistry, Loyola College, Nungambakkam, Chennai-34 for his assistance in herbarium preparation. I would extend my thanks to Mr. Antoine Label, head of our department to provide us with necessary sources and also my fellow co-research scholars for their assistance in writing this paper.

\section{Financial support and sponsorship: Nil.}

Conflict of Interests: There are no conflicts of interest.

\section{REFERENCES}

Al-Saikhan MS, Howard LR and Miller JC.Antioxidant activity and total phenolics in different genotypes of potato (Solanum tuberosum, L.). J Food Sci, 1995; 60:341-343, 347.

Aruoma OL. Free radicals, oxidative stress and antioxidants in human health and disease. J Am Oil Chem, 1998; 75:199-212.

Babu B, Shylesh B, Padikkala J. Antioxidant and hepatoprotective effect of Acanthus ilicifolius. Fitoterapia, 2001; 72:272277.

Bergman M, Varshavsky L, Gottlieb HE and Grossman S. The antioxidant activity of aqueous spinach extract: chemical identification of active fractions. Phytochem, 2001; 58:143 -152.

Brand-Williams W, Cuvelier ME and Berset C. Use of free radical method to evaluate antioxidant activity. Lebenson Wiss Technol, $1995 ; 28: 25-30$ 
Cao G, Sofic E and Prior RL. Antioxidant capacity of tea and common vegetables. J Agric Food Chem, 1996; 44:3426 -3431.

Cheng HY, Lin TC, Yu KH, Yang CM, Lin CC. Antioxidant and free radical scavenging activities of Terminalia chebula. Biol Pharm Bull, 2003; 26:1331-1335.

Dinis TCP, Madeira VMC, Almeida MLM.Action of phenolic derivates (acetoaminophen, salycilate and 5-aminosalycilate) as inhibitors of membrane lipid peroxidation and as peroxyl radical scavengers. Arch Biochem Biophys, 1994; 315:161-169.

Elizabeth K, Rao MWA. Oxygen radical scavenging activity of Curcumin. Int J Pharm, 1990; 58:237-240.

Garratt DC. The quantitative analysis of Drugs. Chapman and Hall ltd, Japan, 1964; 3: 456-458.

Halliwell, B. Oxygen radical, nitric oxide and human inflammatory joints disease. Ann Rheum Dis, 1995; 54:505 510.

Halliwell B, Gutteridge JMC. Free radicals in biology and medicine. Oxford University Press, 1999.

Hatano $\mathrm{T}$, Kagawa H, Yasuhara $\mathrm{T}$, Okuda $\mathrm{T}$. Two new flavonoids and other constituents in licore root: their relative astringency and radical scavenging affects. Chem Pharm Bull, 1988; 36:1090-2097.

Jaggi RK, Kapoor S. Flavonoids - a review of biological activities. Indian Drugs, 1999; 36:668-676.

Janero DR. Malondialdehyde and thiobarbituric acid-reactivity as diagnostic indices of lipid peroxidation and peroxidative tissue injury.Free RadicBiol Med, 1990;9:515-540.

Jegadeeswari P, Nishanthini A, Muthukumarasamy $\mathrm{S}$ and Mohan VR.GC-MS analysis of bioactive components of Aristolochia krysagathra (Aristolochiaceae). J Curr Chem Pharm Sc, 2012; 2:226-232.

Marcocci L, Packer L, Droy-Lefai MT, Sekaki A, GardesAlbert M. Antioxidant action of Ginkgo biloba extracts EGb 761. Methods Enzymol, 1994; 234:462-475.

Meir S. Kanner J. Akiri B. and Hadas SP. Determination and involvement of aqueous reducing compounds in oxidative defense systems of various senescing leaves.J Agric Food Chem, 1995; 43:1813- 1817.

Nilsson J, Stegmark R and Akesson B. Total antioxidant capacity in different pea (Pisumsativum) varieties after blanching and freezing. Food Chem, 2004; 86:501- 507.

Oomah BD, Mazza G, Cui W. Optimization of protein extraction from flaxseed meal. Food Res Int, 1994; 27:355-361.

Oyaizu M. Studies on product of browning reaction prepared from glucose amine. Jpn J Nutr, 1986; 44:307-315.

Ramarathnam N, Osawa T, Ochi $\mathrm{H}$ and Kawakishi S. The contribution of plant food antioxidants to human health. Trends Food SciTechnol, 1995; 6:75.
Ruch RJ, Cheng SJ and Klaunig E. Prevention of cytotoxicity and inhibition of intercellular communication by antioxidant catechins isolated from Chinese green tea. J Carcinog, 1989; 10:1003-1008.

Shirwaikar A, Somashekar AP. Antiinflammatory activity and free radical scavenging studies of Aristolochia bracteolata. Indian J PharmSci, 2003; 65:67-69.

Silva JMRD, Darman N, Fernandez Y and Mitjavila. Oxygen free radical scavenger capacity in aqueous models of different procyanidins from grape seeds. J Agric Food Chem, 1991; 39:1549-1552.

Slater TF. Free-radical mechanisms in tissue injury. Biochem J, $1984 ; 222: 1-15$

Wanasundara PKJPD and Shahidi F. Optimization of hexametaphosphate-assisted extraction of ax seed proteins using response surface methodology. J Food Sci, 1996; 61: 604-607.

Wang Sh, Cao G and Prior R. Total antioxidant capacity of fruits. J Agric Food Chem, 1996; 44:701-705.

Whysner J, Wang CX, Zang E, Iatropoulos MJ, Williams GM. Dose response of promotion by butylatedhydroxyanisole in chemically initiated tumors of the rat fore stomach. Food Chem Toxicol, 1994; 32:215-222.

Yamaguchi F, Ariga T, Yoshimura Y, Nakazawa H. Antioxidative and anti-glycation activity of garcinol from Garciniaindica fruit rind. J Agric Food Chem, 2000; 48:180-185

Yen GC and Hsieh CL. Antioxidant activity of extracts from Du-zhone (Eucommiaulmoides) toward various lipid peroxidation model in vitro. J Agric Food Chem, 1998; 46:3952-3957.

Yuting C, Rongliang Z, Zhongjian J and Yong J. Flavonoids as superoxide scavengers and antioxidants. Free Radic Biol Med, 1990; 9:145-150.

Zhang D, Yasuda T, Yu Y, Zheng P, Kawabata T, Ma Y and Okada S. Ginseng extract scavenges hydroxyl radical and protects unsaturated fatty acids from decomposition caused by iron-mediated lipid peroxidation. Free Radic Biol Med, 1996; 20:145-150

\section{How to cite this article:}

Das TS, Ramesh L, Agastian P. GC-MSanalysis of bioactive constituents of Aristolochia bracteolata Linn with in-vitro antioxidant properties. J App Pharm Sci, 2016; 6 (12): 061-066. 